\begin{tabular}{|c|c|c|c|}
\hline Article Info & RESEARCH ARTICLE & ARAŞTIRMA MAKALESİ & \\
\hline Title of Article & \multicolumn{2}{|c|}{$\begin{array}{c}\text { The Effect Of The Structuring In Walled City } \\
\text { On The Istanbul Fountains And The Current } \\
\text { Status Of The Fountains }\end{array}$} & \\
\hline $\begin{array}{l}\text { Corresponding } \\
\text { Author }\end{array}$ & \multicolumn{2}{|c|}{$\begin{array}{l}\text { Mehmet GÜNDÜZ } \\
\text { Dr., Milli Eğitim Bakanlığı Fatih Gelenbevi Anadolu Lisesi, ekalim02@yahoo.com }\end{array}$} & \\
\hline $\begin{array}{l}\text { Received Date } \\
\text { Accepted Date }\end{array}$ & \multicolumn{2}{|c|}{$\begin{array}{l}12 / 01 / 2020 \\
09 / 04 / 2020\end{array}$} & \\
\hline Author / Authors & Mehmet GÜNDÜZ & ORCID: 0000-0002-4642-4189 & \\
\hline How to Cite & \multicolumn{2}{|c|}{$\begin{array}{l}\text { GÜNDÜZ, M., (2020). The Effect Of The Structuring In Walled City On The Istanbul } \\
\text { Fountains And The Current Status Of The Fountains, Kent Akademisi, Volume, } 13 \\
\text { (41), Issue 1, Pages, 146-162 }\end{array}$} & $\begin{array}{l}\text { Kent Akademisi } \\
\text { Urban Academy }\end{array}$ \\
\hline
\end{tabular}

\title{
Suriçi’ndeki Yapılaşmanın Tarihi İstanbul Çeşmeleri Üzerindeki Etkisi ve Çeşmelerin Mevcut Durumu ${ }^{1}$
}

Mehmet GÜNDÜZ ${ }^{2}$

\begin{abstract}
:
One of the most important elements of Turkish-Islamic architecture is fountains. Fountains are also an important element in Turkish social life. Therefore, hundreds of fountains were built in Istanbul during the Ottoman Empire. However, the developments after the collapse of the Ottoman Empire negatively affected the fountains of Istanbul. Over time, most of the fountains in Istanbul remained idle, some were demolished, some destroyed. Migrations and unconscious urbanization put great pressure on the historical fabric of Istanbul. Various efforts have been made to reduce this pressure, but have not been successful. The bureaucratic multiple division further accelerates the destruction of historical monuments. The fountains are the structures most easily affected by the rapid changes in the city. Within the framework of these concerns and worries, this study was carried out in 2017 with our students in order to identify the fountains in the Historic Peninsula and to provide support and warnings to the relevant institutions in this regard. Within the scope of the study, all the streets in the Historical Peninsula were visited one by one with 235 students and photographs of the fountains found were cataloged. As a result of the study, 346 fountains were found and most of them were at high risk.
\end{abstract}

KEYWORDS: Historical Fountains, Suriçi, Ottoman, Istanbul

ÖZ:

Türk-İslam mimarisinin en önemli öğelerinden biri çeşmelerdir. Çeşmeler Türk toplumsal hayatında da önemli bir öğesidir. Bu yüzden Osmanlı Devleti döneminde İstanbul'da yüzlerce çeşme yapılmıştır. Ancak Osmanlı Devleti’nin çöküşünden sonra yaşanan gelişmeler İstanbul çeşmelerini olumsuz yönde etkilemiştir. Zaman içerisinde İstanbul çeşmelerinin çoğu atıl kalmış, bazıları yıkılmış, bazıları ise yok olmuştur. Göçler ve bilinçsiz şehirleşme İstanbul'un

${ }^{1}$ Bu makale 20-22 Haziran 2019 tarihinde İstanbul'da gerçekleşen 1. İstanbul Uluslararası Coğrafya Kongresi’nde “Suriçi’ndeki Yapılaşmanın Tarihi Çeşmeler Üzerindeki Etkisi ve Çeşmelerin Mevcut Durumu" başlığıyla sunulan sözlü bildirinin genişletilmiş halidir.

$\mathrm{Bu}$ çalışmanın saha araştırmasına Fatih Gelenbevi Anadolu Lisesi’nde 2016-2017 eğitim-öğretim yılında 10. sınıfta okuyan öğrenciler katkı sunmuştur. Bu çalışma onların üstün gayret ve çabaları sonucu gerçekleşebilmiştir. Katkılarından dolayı kendilerine teşekkürlerimi sunuyorum.

2 Ministry of Education, Fatih Gelenbevi Anatolian High School, ekalim02@yahoo.com 
tarihi dokusu üzerinde büyük bir baskı oluşturmuștur. Bu baskıyı azaltmaya yönelik çeșitli çalıșmalar yapılmıș ancak başarılı olunamamıştır. Bürokratik çoklu bölünmüşlük ise tarihi eserlerin yok olmasını daha da hızlandırmaktadır. Çeşmeler boyutları bakımından şehrin geçirdiği hızlı değişimlerden en kolay etkilenen yapılardır. Bu kaygı ve endişeler çerçevesinde öğrencilerimizle birlikte Tarihi Yarımada'daki çeşmeleri tespit etmek ve ilgili kurumlara bu konuda destek ve uyarılarda bulunmak amacıyla 2017 yılında bu çalışma gerçekleştirilmiştir. Çalışma kapsamında 235 öğrenciyle Tarihi Yarımada'daki bütün sokaklar tek tek gezilmiş ve tespit edilen çeşmelerin fotoğrafları çekilerek katalog haline getirilmiş̧ir. Çalışma sonucunda 346 adet çeşme tespit edilmiş ve bunların çoğunun büyük risk altında oldukları görülmüştür.

ANAHTAR KELIMELER: Tarihi Çeşmeler, Suriçi, Osmanlı, İstanbul

\section{Suriçi'ndeki Yapılaşmanın Tarihi İstanbul Çeşmeleri Üzerindeki Etkisi Ve Çeşmelerin Mevcut Durumu}

\section{GİRIŞ:}

Türkiye farklı dönem ve medeniyetlerden kalan zengin bir kültürel mirasa sahiptir. Bu zengin mirasın önemli bir parçasını mimari eserler oluşturmaktadır. Mimarinin medeniyet tarihinde ve cemiyet hayatında kesin bir ifadesi vardır. Örneğin, uzaktan minareleri seyredilerek yaklaşılan bir yerde mutlaka İslâm'ın yaşamış veya yaşamakta olduğunu anlaşlır (Çetintaş, 1944:125-147). Aynı şekilde Türkiye'de çeşmelerin, şadırvan ve sebillerin çokluğundan da Türklerin suya, temizliğe ve hayırseverliğe düşkünlüğünü anlaşılır.

Türklerin hayatında su günlük yaşamın en önemli unsurudur ve birçok farklı alanda onların ilham kaynağıdır. Nitekim geçmişte Türkler evinin avlusunda bir akarsuyun sesinden uzak kalmamaya çalışmıştır. İslam dünyasında medresede okuyan öğrenci, ders okutan âlim, camide Allah'a ibadet eden kul, hastanede hastaları tedavi eden doktor suyun sesinden istifade etmesini bilmiş̧ir. Hakikaten Selçuklu, Osmanlı ve Anadolu Beylikleri döneminde yapılan mimari eserlerin önünde bir çeşme veya avlusunda bir havuz, şadırvan veyahut da köşesinde bir sebil olmasına dikkat edilmiştir (Çetintaş, 1944:126-129). Türk-İslam medeniyetinde çeşmelerin hayatın merkezinde yer aldığı İstanbul gibi birçok şehir bulunmaktadır.

İstanbul farklı kültürlerin izlerini taşıyan dünyadaki en önemli şehirlerden biridir. Hristiyanlığın önemli merkezlerinden biri olan İstanbul Müslümanlar tarafından fethedildikten sonra Müslümanlığın da önemli merkezlerinden biri olmuştur. Fetihten sonra Osmanlılar şehri adeta yeniden inşa etmiştir. Nitekim Osmanlı Devleti yaklaşık beş asır kendisine başkentlik yapmış İstanbul'u birçok eserle süslemiştir. Bu eserlerin belki de en yaygını çeşmelerdir. Fakat Osmanlı Devleti'nin çöküşünden sonra yaşanan gelişmeler İstanbul çeşmelerini de olumsuz yönde etkilemiştir. Zaman içerisinde İstanbul çeşmelerinin çoğu atıl kalmış, bazıları yıkılmış, bazıları ise tamamen yok olmuştur. Bu çeşmeleri kurtarmak için çeşitli çalışmalar yapılmış olmakla beraber bunlar yeterli olmamıştır. İstanbul çeşmeleri hala büyük bir tehlike altında bulunmaktadır. Bu yüzden günümüz İstanbul'unda ayakta kalabilmiş çeşmelerin mevcut durumunu incelemek ve bu konuda elde edilen verileri İstanbul Büyükşehir Belediyesi, Fatih Belediyesi ve Vakıflar Bölge Müdürlüğü ile paylaşmak elde kalan çeşmelerin varlıklarının korunması için elzemdir. Bu gaye ile çeşmelerin tarihi süreç içerisinde geçirdiği değişimler incelenmiş ve 2017 yllında İstanbul Suriçi'deki tarihi çeşmelerin mevcut durumunu tespit etmek için saha çalışması yapılmıştır.

\section{1. Çalışmanın Amacı ve Yöntemi}

Farklı mimari üslup ve biçimlerde yapılmış olan çeşmeler Türk hayat biçiminin bir parçası olarak suyu insana ulaştıran şaheserlerdir. Çeşmeler şehrin her yerine dağılan mimari eserler olarak şehri bir açıkhava müzesine dönüştürmektedir. Buna rağmen çeşmeler boyutları sebebiyle şehrin geçirdiği hızlı değişimlerde niteliklerini en kolay yitiren mimari eserlerdir (Çetintaş, 1944:126-129). İstanbul'daki çeşmeler göç, inşaat ve doğal afetler gibi çeşitli etkenlerin yoğun baskına maruz kalmaktadır. Bürokratik çoklu bölünmüşlük ise bu tarihi eserlerin yok olmasını daha da hızlandırmaktadır. Bu kaygı ve endişeler çerçevesinde Suriçi'nde bulunan tarihi İstanbul çeşmelerinin son durumunu tespit etmek amacıyla bu çalışma yapılmıştır. Ayrıca bu çalışmayla ilgili kurumlara tarihi çeşmelerin korunmasıyla ilgili destek olunması, uyarıda bulunulması ve çalışmada yer alan öğrencilerin bilinçlendirmesi hedeflenmiştir. 
Nitel desenli bir araştırma olan bu çalışmada durum çalışması yapılarak Suriçi'nde bulunan tarihi çeşmelerinin mevcut durumları incelenmiştir. Bu çerçevede Fatih Gelenbevi Anadolu Lisesi’nde 2016-2017 eğitim-öğretim yılında 10. sınıfta okuyan toplam 235 öğrenci bu çalışmaya katkı sağlamıştır. Çalışma kapsamında Suriçi’nde yer alan 57 mahalle için ortalama 4 kişiden oluşan 57 grup oluşturulmuştur. Öncelikle her grup inceleyeceği mahallenin sınırları belirlemiştir. Daha sonra öğrenciler sorumlu oldukları mahallenin sokaklarını tek tek inceleyerek tarihi çeşmeleri tespit etmiş ve bunları fotoğraflayıp raporlandırmıştır. Çalışma kapsamında çeşmelerin durumuyla ilgili ihtiyaç duyulduğunda mahalle sakinlerinin, muhtarların, esnafların ve diğer ilgililerin bilgilerine başvurulmuştur. Çalışmada elde edilen veriler çeşmelerle ilgili daha önce yapılmış araştırmalarla karşılaştırılmıştır. Elde edilen veriler daha sonra katalog haline getirilmiştir. Bu katalogda her bir çeşmenin yer aldığ 1 adres, çeşmenin mevcut durumu, çeşmenin fotoğrafları ve inceleme tarihi yer almıştır.

\section{2. İstanbul'da Suyun Tarihi}

Su İstanbul için neredeyse tarihin her döneminde önemli bir problem olmuştur. Nitekim Doğu Roma’nın ilgilendiği sorunların başında şehrin su ihtiyacının nasıl karşılanacağı meselesi gelmiş ve bu amaçla Bozdoğan, Jüstinyen ve Andronikos su kemerlerini yapmıştır (Tanışık, 1943:C.I:VI-VII). Doğu Romalılar şehir dâhilinde Altımermer'de, Edirnekapı'da ve Sultan Selim'de bugün Çukurbostan olarak bilinen yerlerde büyük ve açık sarnıçlar yapmıştır (Çetintaş, 1944:129). Çukurbostanlarda toplanan sular Yerebatan, Binbirdirek, Zeyrek ve Sultan Selim sarnıçlarıyla Yedikule'deki İmrahor İlyasbey ve Lâleli'deki Bodrum camilerinin altlarında depolanmış ve kullanılmıştır. 425 yılında İstanbul'da 4 sarnıcın olduğu bilinmektedir (Mango, 2006:44). M.S. VII. yüzyılda Herakliyos bu çukur bostanları toprakla doldurtmuş ve buraları bahçe haline getirmiştir (Tanışık, 1943:C.I:VI-VII). İstanbul'daki bu büyük sarnıçlar dışında birçok evin kendi özel sarnıcı da bulunmaktaydı. Doğu Romalılar ayrıca şehir içindeki bazı yerleri ayazma olarak kullanmıştır (Çetintaş, 1944:129). Bu sarnıçlarda, kuşatma korkusu nedeniyle yağmur suyu ve diğer suları depolamışlardır. Zira uzun süren kuşatma ve savaşlarda şehrin su ihtiyacını kolay bir şekilde temin etmek şehrin savunulmasında son derece önemliydi (Demirel, 1992:169; Strzygowski ve Forchheimer, 1893).

İstanbul'un Osmanlılar tarafından fethi sırasında şehrin su tesisatının harap olduğu anlaşılmaktadır. Fatih Sultan Mehmet fethettikten sonra harap durumdaki su yollarını ve bunlara bağlı olan yapıların onarımı için imar çalışmaları yaptırmıştır. Roma devrinden beri kente su veren tesisler bu dönemde onarılmış, Şadırvan, Turunç, Mahmutpaşa ve Fatih suyolları yapılmıştır (Kılınçer, 2007:16; Ayverdi, 1953:41-42). Nitekim Tursun Bey Tarih-i Ebü'l-Feth adlı eserinde, şehrin su sıkıntısını çözmek için Doğu Roma döneminden kalan eski su yollarının onarıldığını ve yenilerinin yapıldığını aktarmıştır (Aysel, 2008:224).

Genel olarak su işini Doğu Romalılardan daha ciddi düşünen Türkler sarnıçlara iltifat etmemiş, temizliğine inanmamış ve ayazmaları da Rumların kullanımına bırakmıştır (Çetintaş, 1944:129-130). Durgun suyun temiz olmadığını düşünen Türkler akar suya önem vermiştir. XVI. yüzyıla kadar gittikçe kalabalıklaşan İstanbul'un su ihtiyacı da giderek artmıştır. Bu yüzden Kanuni Sultan Süleyman Mimar Sinan’1 bu sorunu çözmekle görevlendirmiştir. Bu dönemde İstanbul'un en önemli su rezervlerinden biri Belgrad Ormanı'ydı. Bu orman dâhilinde yedi adet bent yapılmış ve bunlardan dördü İstanbul ve üçü de Beyoğlu cihetine su vermiştir (Tanışık, 1943:C.I:VI-VII). Nitekim Mimar Sinan, Kırkçeşme sularını Belgrad Ormanı, Kemerburgaz ve Eyüp sırtlarından akıtıp kanallar ve kemerler aracılığıyla Eğrikapı'ya kadar getirmiştir. Bu proje için Osmanlı Devleti büyük paralar harcamıştır (Çetintaş, 1944:129-130). Ancak bu dönemde İstanbul'a bu suyun getirilmesine karşı çıkanlar da olmuştur. Sadrazam Rüstem Paşa, İstanbul'a su getirilmesi halinde şehrin nüfusunun artacağı, halkın et, ekmek ve zahire tedarikinin güçleşeceği, ordunun iaşesini temin etmenin zorlaşacağı, İstanbul'un erzak ve zahire narhlarının bozulacağı gibi sebepleri ileri sürerek karşı çıkmıştır (Çubukçuoğlu, 1936).

\section{1. İstanbul Çeşmeleri}

Osmanlı toplumunda su hayır ve temizlikle eşdeğerdedir. Bu alandaki hizmetler ile çeşmeler dinî bir kültürün pratiğe uygulanmış halidir. Bu yüzden herkes elindeki imkânlar çerçevesinde su getirme ve çeşme yaptırma faaliyetlerine katkıda bulunmaya çalışmıştır (Demirel,1992:162). İstanbul'da yüzyıllar içinde oluşan birikim sayesinde farklı şekil ve üsluplarda inşa edilmiş yüzlerce çeşme bulunmaktadır. Burada yaşamış ve görev yapmış birçok devlet adamı ile hali vakti yerinde olan birçok kişi sosyal, ekonomik ve siyasi güçleri ölçüsünde çeşme yaptırmıştır. Bu çeşmeler sadece ihtiyaç olduğu için inşa edilmemiş aynı zamanda banileri tarafindan şan ve şeref göstergesi olarak da düşünülmüştür (Kılınçer, 2007:18). Sebil, pınar veya çeşmeler şehirlerdeki fiziki yapının oluşumuna da etkili olmuştur (Demirel,1992:162). 
İstanbul çeşmeleri yüzyıllar içinde döneminin mimari anlayıșına göre yapı ve kullanım bakımından belli değișikliklere uğramıştır. İstanbul'da Osmanlı döneminden günümüze kalan en eski çeşme 1485 yılında yapılan Davut Paşa Çeşmesi'dir (Ek-1). Bu çeşme sivri kemerli bir nişle, mermer bir yalaktan oluşmaktadır (Aslanapa, 2004:622). XV., XVI. ve XVII. yüzyılda çeşmeler klasik bir kemer içinde düz bir ayna taşı, kitabe, tene ve teknenin şekilleri ile su haznelerinden oluşurken XVIII. yüzyılda Batılılaşmanın etkisiyle kemerler çok daha dekoratif, içi süslemeli, barok tarzında gölgelikli, cephelerde natürmort kabartmalar, rumi desenlerden oluşmuştur. Ayrıca erken dönem çeşmelerinde devamlı suretle suyu akan salma lüleli biçimindeki çeşmeler daha çok iken Kanuni döneminde salma lülelerin yerini musluklar almıştır (Kılınçer, 2007:18; Arel, 1975:86-98). Ancak çeşmelere musluk takılması halkın tepkisine yol açmışır. Akar suyla bahçe ve bostanlarını suladıklarını dile getiren halk kimi zaman muslukları kırmaktan veya gece muslukları açık bırakmaktan geri durmamıştır. Sorun ancak 1564'te alınan önlemlerle halledilebilmiş ve isteyenlerin kendi parasıyla çeşme yapmalarına müsaade edilmiştir (Çubukçuoğlu, 1936).

Osmanlı çeşmeleri yapılış amaçları ve biçimlerine göre ise belli başlı şu kategorilere ayrılabilir:

1-Meydan Çeşmeleri

2- Köşe başı Çeşmeleri

3- Sokak Çeşmeleri

4- Sebil Çeşmeler

5- Âbidevi Çeşmeler

6-Duvara bitişik Çeşmeler

7- Çeşme-i sebiller

8- Namazgâh Çeşmeleri

9- Oda Çeşmeleri

10- Sütun Çeşmeler

11- Selsebiller (Tanış1k, 1943:C.I:VI; Kılınçer, 2007:20-22).

Bu kategori nihai bir kategori olmayıp bazı araştırmacılar farklı kategorilerde öne sürülmüştür. Mesela Semavi Eyice (1993:279) şadırvan, oda çeşmesi ve muslukları Türk mimarisindeki çeşme tanımının dışında kalan su tesisleri olarak nitelemiştir.

Meydan ve köşe çeşmeleri ile yanlarında sebilleri bulunan büyük ve ihtişamlı çeşmeler; arkalarında veya biraz üst taraflarında birer su deposu veya haznesine sahip iken küçük ve sokak çeşmeleri sularını doğrudan doğruya künk veya borulardan almıştır. Bunlardan bazıları lüleli, bazıları musluklu, bir kısmı tekneli, bir kısmı da yalaklıdır. Osmanlı Devleti her eve su vermek yerine belli merkezlere su vermeyi tercih etmiştir. Bu yüzden çeşmeler yapıldığı yere göre özel bir şekilde konumlandırılmış ve daha sonra inşa edilen yapılar da bu doğal plana bağlı kalarak çeşmenin etrafında konumlanmıştır (Tanışık, 1943:C.I:VI). XVIII. yüzyıl İstanbul mimarisinde klasik çeşme tipolojisinden farklı olarak tasarlanan meydan çeşmeleri, gündelik hayatın merkezi olmuştur (İgüs, 2014:684). Çeşmelerin İstanbul sokaklarına pırlantalar gibi serpildiklerini söyleyen Yüksek Mimar W. Schütte (1942) küçük veya büyük olsun çeşmelerin büyük aşk sonucu yapıldıklarının göze çarptığını belirtmiştir. Çeşmeler her ne kadar dört köşeli bir kutu gibi gözükse de insanların su ihtiyacını karşıladığını, onları güneş ve yağmurdan koruduğunu belirten Schütte duvarları kitabe, tezyinat, çiçekler ve beyitlerle kaplı olan çeşmeleri nev'i şahsına münhasır eserler olarak bütün bir mahallenin şahdamarı olarak tarif etmiş̧ir. Schütte'nin şehri süsleyen sanat şaheserleri olarak betimlediği çeşmelerin İstanbul'da bu kadar bol olmasının nedeni aslında suyunun çok olmasıyla değil bilakis az olmasıyla ilgilidir. Hem içme hem de sulama gibi maksatlarla yapılan çeşmeler sularını Terkos, Kırkçeşme, Halkalı, Elmalı ve Hamidiye'den almıştır (Tanışık, 1943:C.I:VI). 


\subsubsection{Suriçi'ndeki Çeşmelerin Geçirdiği Değişimler ve Dönüşümler}

Cumhuriyet döneminde İstanbul, Osmanlı Devleti’nin başkenti olması sebebiyle uzun süre gözden düşmüştür. Bu dönemde sanat değerine sahip çeşme yapılmadığını söyleyen Semavi Eyice'ye (1993:286) göre İstanbul'da vakıf sularının belediyeye devredilmesi ve çeşmelerin körletilmesi sebebiyle çeşme vakfedilmesi geleneği bitmiştir. Böylelikle adeta çeşmelerin hayat hakları ellerinden alınmıştır (Ertuğ, C.I:21).

Ekonomik sebeplerle birçok kişi İstanbul'a göç etmektedir. Nüfusunun sürekli artması şehrin tarihi dokusu üzerinde bir baskı oluşturmaktadır. Bu baskı özellikle 1940'lı yıllardan sonra giderek artmıştır. Nitekim 1940'lı yılların ikinci yarısından itibaren modernleşme adına başlayan hızlı ve kontrolsüz kentleşmeyle kültür ve doğa varlıkları ciddî ve önüne geçilemeyen bir yıkım/yok olma sürecine girmiş̧tir. Köyden kente hızlı göçün getirdiği plânsız kentli nüfusun artışı İstanbul'da imar planlarıyla öngörülen konut stoğunun çok üstünde bir talebin oluşmasına neden olmuş ve bu durum kültür varlıklarının yıkımına ve tahribine zemin hazırlamıştır. 1950'lerde modernleşmenin apartmanlaşmayla eşdeğer tutulduğu bir yaklaşımın kültür varlıklarının yok edilmesini bir "gelenek" hâline getirdiği söylenebilir. Bu geleneğin oluşumunda özellikle 1950'li yıllardaki devlet organlarının etkisini de yok saymamak gerekir (Asatekin, 2004:14-16).

1950'li yıllarda yapılan imar çalışmaları İstanbul'da birçok kültür varlığını yok etmiştir. Bu dönemde özellikle yol ve bulvar çalışmaları sonucunda birçok tarihi eser yok olmuştur. 1950'li yıllarda basılmış ve Demokrat Parti'nin icraatlarını anlatan İstanbul'un Kitabı adlı eserde İstanbul'da yapılan yol ve bulvar çalışmalarından bahisle İstanbul'un Başbakan Adnan Menderes'in büyük gayretiyle ikinci defa fethedildiğini yazmıştır. Menderes'in İstanbul'daki ıstıraba, dağınıklığa ve derbederliğe karşı bir medeniyet zaferi kazandığını belirten mezkûr yayın İstanbul'un yolları, limanları, sanayi tesisleri, binaları ve yeni hayat merkezleriyle taptaze ve medeni bir hüviyete kavuştuğunu belirtmiştir (İstanbulun Kitabı: 5) (Harita-1).

Harita-1: 1950'li Yıllarda İstanbul'da Açılan Yol ve Bulvarı Gösteren Harita

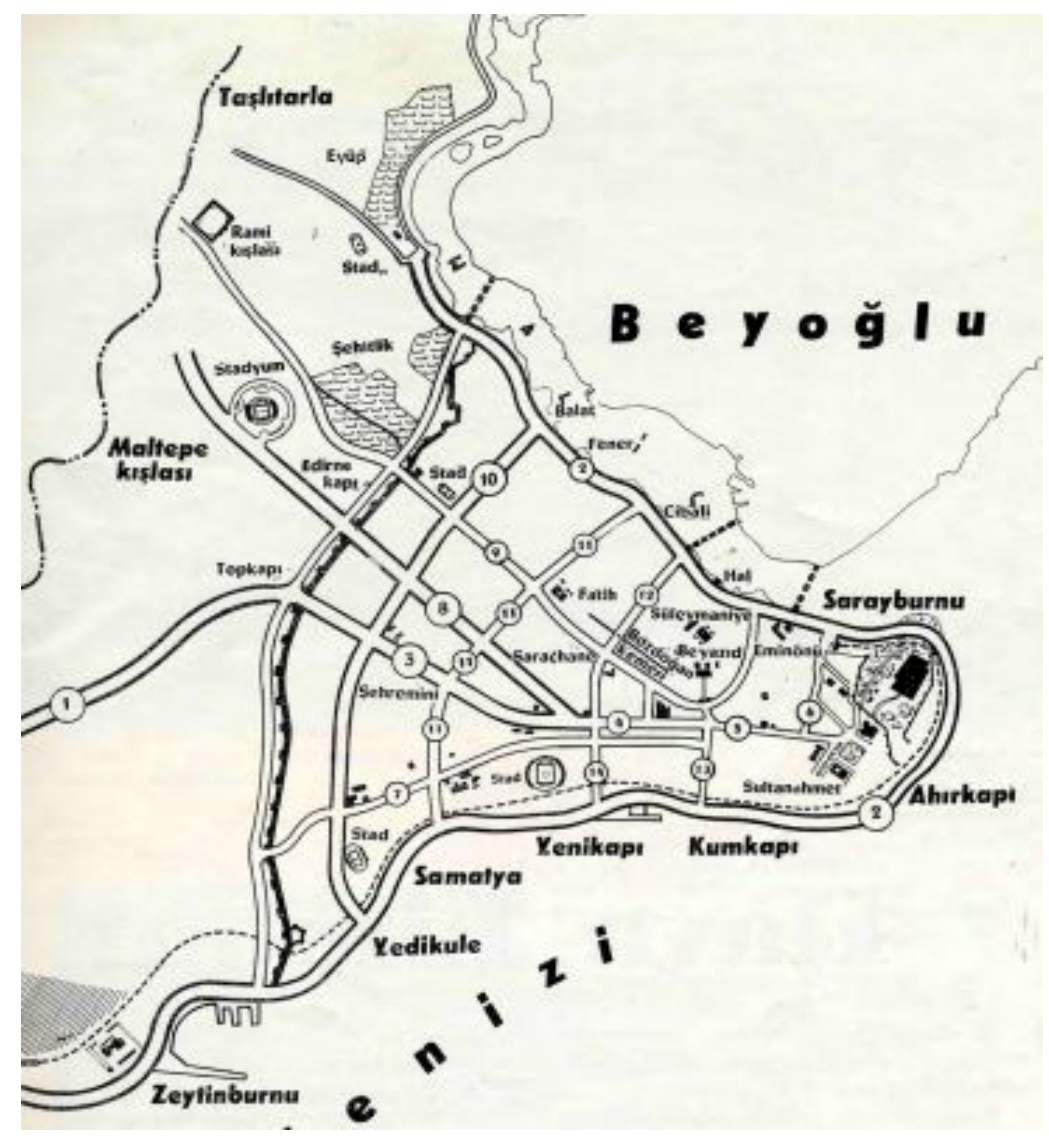

Kaynak: İstanbulun Kitab1:7. 
Resim-1: 1950’li Yıllarda Saraçhane ve Çevresi.

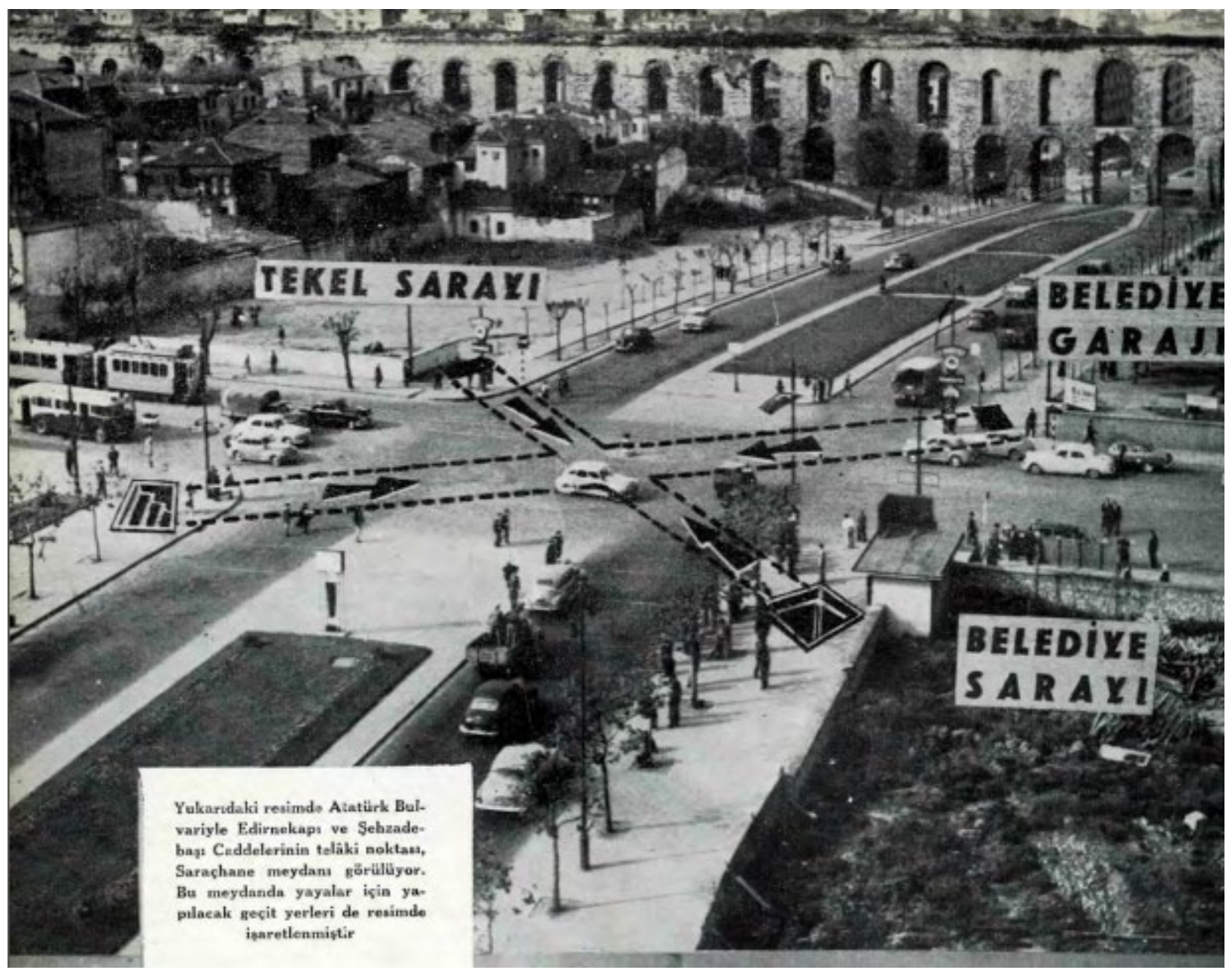

Kaynak: İstanbulun Kitabı:45.

1950'li yıllarda (Resim-1) Tarihi Yarımada'da açılan yol ve bulvar çalışmaları sebebiyle şu çeşmeler yıkılmıştır:

1. Çeşme: Topkapı civarındaki çeşme.

2. Çavuş Çeşmesi

3. Yusuf Paşa Çeşmesi

4. Aksaray Çeşmesi

5. Oğlanlar Çeşmesi

6. Hakkı Paşa Çeşmesi

7. Camcılar Camii Çeşmesi

8. Aksaray Valide Çeşmesi 


\section{Vezir Ahmet Paşa Çeşmesi \\ 10. Kırk Çeşmeler \\ 11. Yaver Ağa Meydan Çeşmesi \\ 12. Lâleli Baba Çeşmesi (Ünsal: 10-43).}

Vakıf Hayrât-1 Şerîfe Defterlerinde yer alan ancak günümüze ulaşmayan Eminönü Yeni Cami sahil bölgesindeki çeşmeler ise şunlardır:

\section{Nevşehirli Damat İbrahim Paşa Çeşmesi}

2. Şahsultan Çeşmesi

3. Vezir Çeşmesi

4. Gül Hasan Paşa Çeşmesi

5. Kanuni Sultan Süleyman Çeşmesi

6. Çaşnigir Çeşmesi

7. Rüstem Paşa Çeşmesi

8. Hacı Ahmet Efendi Çeşmesi

9. Yemiş Caddesi Çeşmesi

10. Yavuz Er Sinan Çeşmesi (Sefer, Ahunbay, 2015: 78-120).

Bu yıkıma benzer bir yıkım da 1980'li yıllarda gerçekleşmiştir. 1980'lerde İstanbul Büyükşehir Belediyesi Haliç'i güzelleştirmek adına kıyı boyundaki geleneksel konutları yıkmıştır. İstanbul'un yoğun nüfusu, şehre taşınan ama şehirleşemeyen bir grubun ranttan pay almasına neden olmuştur. Kaçak yapılaşma kentin doğasını büyük oranda bozmuştur. Ayrıca neredeyse her seçim döneminde ortaya çıkan "imar affı geleneği" bu yıkımı uzun vadede desteklemiştir (Asatekin, 2004:14-16). Yapılan çalışmalara bakıldığında imar adı altında sistemli olmasa da bilinçsizce şehir dokusunun büyük oranda tahrip edildiğini söylenebilir. Gelenbevi Anadolu Lisesi ve çevresine bakmak bile İstanbul'un zaman içeresinde geçirdiği değişimi görmek için yeterlidir. 


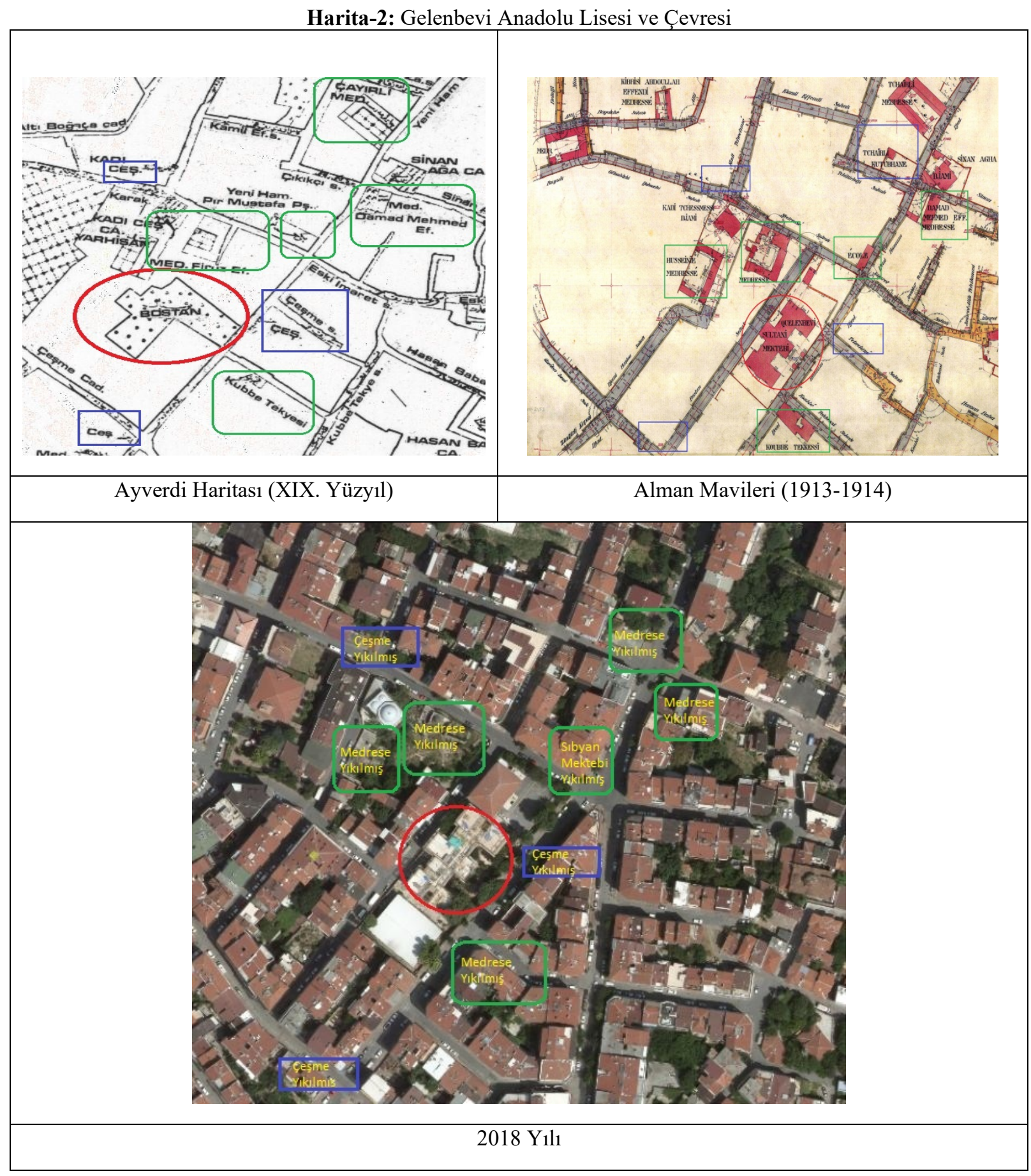

Kaynak: https://gis.fatih.bel.tr/webgis/

Yukarıda yer alan ve farklı dönemlere ait üç haritada da görüldüğü üzere bugün Gelenbevi Anadolu Lisesi'nin bulunduğu muhitte önemli değişikliklerin yaşanmıştır. XIX. yüzyılda bölgede bulunan üç çeşmenin XX. Yüzyıla gelindiğinde yok olduğu görülmektedir (Harita-2). Alman Mavilerinde (Harita-2) çeşmeler görülmemekle beraber Çeşme ve Kadı Çeşmesi adlı sokakların var olduğu, Çeşme Caddesinin adının ise Gelenbevi Sokağı olarak değiş̧tirildiği görülmektedir. 2018 yılına gelindiğinde ise bölgenin büyük oradan değiştiği gözlemlenmektedir. Çeşmeler dışında okulun çevresindeki diğer bazı önemli yapıların da yıkılmış olduğu görülmektedir. Günümüzde (Harita-2) Kubbe Tekkesi tamamen yok olmuş ve yerine konut inşa edilmiştir. Gelenbevi Mektebi Sultanisi’nin arkasında bulunan iki medrese bugün tamamen yıkılmış ve sadece temel duvarları kalmıştır. Okulun Haliç tarafında 
bulunan Sıbyan Mektebi tamamen yok olmuş ve yerine konut inșa edilmiștir. Yine aynı yönde bulunan Damat Mehmet Efendi Medresesi de aynı akıbete uğramıştır. Bu medresenin karşında bulunan medrese ve kütüphanenin sadece bir kısmı ayakta kalmış ve yeri bugün otopark olarak kullanılmaktadır.

Şehrin bu değişiminde hem insan müdahalesi hem doğal afetler etkili olmuştur. 13 Ağustos 1324'deki (26 Ağustos 1908) Çırçır, 10 Temmuz 1327'deki (23 Temmuz 1910) Aksaray ve Mercan, bir gün ara ile Balat, 21 Mayıs 1328'deki (3 Haziran 1912) İshak Paşa, 31 Mayıs 1334'teki (13 Haziran 1918) Cibâli - Cerrah Paşa - Şehremini, aynı senenin ağustosundaki Vefa, 1335 (1919) senesinde Karagümrük'de meydana gelen yangınlar İstanbul'un büyük bir kısmını tahrip etmiştir. Ayrıca bu yangınlardan sonra az çok hasar görmüş eserler henüz ayakta ve güzergâhları belli iken, hemen işe başlanmadığı için kurtarılması mümkün olanlar da yok olmuştur. (Ayverdi, 1958:5).

\subsection{2. İstanbul Çeşmelerini İhya Çalışmaları ve Çeşmelerle İlgili Sayısal Veriler}

Sözlükte çeşmenin göz gibi olan delik ve bu delikten akan su diye tarif edildiğini belirten Selim Sirrı Tarcan eğer bu delikten su akmıyorsa çeşmenin lüzumsuz bir lüks eşyası yerine geçeceğini söylemiş̧tir. Tarcan 1938 yılında İstanbul'daki çeşmelerin durumundan bahsederken birçoğunun çalışmadığını, bazılarının musluğunun kopuk mermerinin kırık olduğunu ayrıntılarıyla anlatmıştır. Selim Sırrı Tarcan'ın 1938 yılında Taksim'den Fatih'e yaptığı yürüyüşte gördükleri İstanbul'daki tarihi çeşmelerin durumunu ortaya koyması bakımından önemlidir. Tarcan Taksim'de gördüğü çeşmenin musluğunun kopuk ve mermerinin kırık olduğunu, Galatasaray'da da benzer bir manzara ile karşılaştığını belirtmiştir. Bahçekapısı'nda çok sanatkârane yapılımış sebilin suyunun akmadığını yazan Tarcan, Topkapı Sarayı ve Ayasofya çevresindeki çeşme ve sebillerden de su akmadığını aktarmıştır. Divanyolu'ndaki, Direklerarası'ndaki, Atikalipaşa Camisi'ndeki ve Şehzade Camisi'ndeki çeşmelerin de benzer durumda olduğunu aktarmıştır (Tarcan, 1938). 1942 yılında ise Yüksek Mimar W. Schütte'de benzer değerlendirmede bulunarak iyi durumda yalnız birkaç çeşmenin olduğunu, çoğunun ise harap hale geldiğini yazmıştır. Schütte bazı çeşmelerin çatılarının olmadığını, bazılarının renklerinin solduğunu, hemen hemen hepsinin kirli olduğunu da eklemiştir (Schütte, 1942). Yapılan değerlendirmeler İstanbul'daki tarihi çeşmelerin bu dönemde bakımsızlık ve duyarsızlıktan kötü durumda olduğu anlaşılmaktadır.

İstanbul'daki tarihi çeşmeleri korumak ve kurtarmak amacıyla farklı zamanlarda yapılan çalışmalar da bulunmaktadır. 1939 yılında İstanbul Belediyesi'nin harap haldeki tarihi çeşmeleri onaracağı basına yansımıştır (Tarihi Çeşmeler, 1939). Yine Kırkçeşmelerin ihya edilmesi 1950'de gündeme gelmiştir (Kırkçeşme Suları İhya..., 1950). (Milliyet, 17.7.1950:7). Nihad Sami Banarlı (1958:4) İstanbul imarında onarılan, ihya edilen çeşmelerin sadece yollardaki birer nefis sanat eseri değil, aynı zamanda birer aziz teselli unsuru olarak gözü ve gönlü doldurduğunu belirterek çeşmelerin onarılmasını desteklemiştir. Güneş gazetesi 1985 ve 1986 yılında çeşmelerin onarılması için bir kampanya başlatmıştır. İstanbul Belediyesi ve Güneş gazetesi öncülüğünde yapılan çalışmalar kapsamında 18 Mart 1985'te Yıldız Teknik Üniversitesi’nde "1. Tarihi İstanbul Çeşmeleri Semineri” düzenlenmiştir (Tarihi İstanbul Çeşmeleri, 1985). "Tarihi İstanbul Çeşmeleri Kurtarılmalıdır" kampanyası kapsamında 28 Nisan-3 Mayıs 1986 tarihleri arasında Atatürk Kültür Merkezi'nde düzenlenen sergide ise biten ve onarımı devam eden çeşmeler yer almıştır (Tarihi İstanbul Çeşmeleri, 1986). Program kapsamında ilk olarak 41 çeşme onarıma alınmıştır (Köprülü Hemşire Çeşmesi, 1985). Daha sonra bu sayı 50'ye çıkmıştır. Bu kampanya çerçevesinde 8'i Tarihi Yarımada'da olmak üzere İstanbul'da toplam 50 çeşme onarılmıştır (Güneş, 1985). 2000'li yılların başından itibaren tarihi çeşmelerin korunması için daha fazla mesai ve para harcandığı gözlemlenmektedir. 
Tablo-1: Suriçi'nde Onarılan veya İhya Edilen Çeșmeler

\begin{tabular}{|c|c|c|c|}
\hline Yılı & $\begin{array}{l}\text { Onaran veya } \\
\text { İhya Eden } \\
\text { Kurum }\end{array}$ & Onarılan veya İhya Edilen Çeşmeler & $\begin{array}{l}\text { Onarılan } \\
\text { veya İhya } \\
\text { Edilen } \\
\text { Çeşme } \\
\text { Sayısı }\end{array}$ \\
\hline 2012 & $\begin{array}{l}\text { İstanbul } \\
\text { Büyükş̧ehir } \\
\text { Belediyesi }\end{array}$ & $\begin{array}{l}\text { Sivrikoz Çeşmesi, Şerife Zeliha Hanım Çeşmesi, Mehmet } \\
\text { Ağa Çeşmesi, Kadı Çeşmesi, Laleli Camii Çeşmesi, Akbıyık } \\
\text { Saka Çeşmesi ve Kapı Ağası Çeşmesi }\end{array}$ & 7 \\
\hline 2013 & $\begin{array}{l}\text { İstanbul } \\
\text { Büyükşehir } \\
\text { Belediyesi } \\
\end{array}$ & $\begin{array}{l}\text { Nevşehirli Damat İbrahim Paşa Çeşmesi, Ferruh Kethüda } \\
\text { Cami Çeşmesi, Kanuni Süleyman Han Çeşmesi ve İsimsiz } \\
\text { Çeşme (Yusuf Şucauddin Camii) }\end{array}$ & 4 \\
\hline 2014 & $\begin{array}{l}\text { İstanbul } \\
\text { Büyükssehir } \\
\text { Belediyesi }\end{array}$ & $\begin{array}{l}\text { Şerife Zeliha Hanım Çeşmesi, Eyüpzade Şükrü Bey Çeşmesi } \\
\text { ve Hacı Necip Bey Çeşmesi }\end{array}$ & 4 \\
\hline 2015 & $\begin{array}{l}\text { İstanbul } \\
\text { Büyükssehir } \\
\text { Belediyesi }\end{array}$ & $\begin{array}{l}\text { Mahpeyker Kösem Valide Sultan Çeşmesi ve Ayşe Sultan } \\
\text { Çeşmesi }\end{array}$ & 2 \\
\hline 2016 & $\begin{array}{l}\text { İstanbul } \\
\text { Büyükşsehir } \\
\text { Belediyesi }\end{array}$ & $\begin{array}{l}\text { Beşir Ağa Çeşmesi (Mercan Kapısı Yanı), Beşir Ağa } \\
\text { Çeşmesi (Sultanahmet), Hac1 Eyüpzade Şükrübey Çeşmesi, } \\
\text { Hacı Necipbey Çeşmesi, Hekimoğlu Ali Paşa'nın Validesi } \\
\text { Çeşmesi ve Mehmet Paşa (Cerrah) Çeşmesi }\end{array}$ & 6 \\
\hline 2017 & $\begin{array}{l}\text { İstanbul } \\
\text { Büyükşehir } \\
\text { Belediyesi }\end{array}$ & $\begin{array}{l}\text { Abdullah Ağa Çeşmesi, Ahmet Kethüda (Cağaloğlu), Ayşe } \\
\text { Sultan Çeşmesi, Beşir Ağa Çeşmesi (Sultanahmet), Bozdoğan } \\
\text { Kemeri Cad. Üzerindeki Çeşme, Ebu Bekir Ağa Çeşmesi, } \\
\text { Elhac Mustafa Efendi Çeşmesi, Gülhane Park1 Çeşmesi, } \\
\text { KUDEB Sokağ1 Çeşmesi, Mirahur Hasan Ağa Çeşmesi ve } \\
\text { Muslu Ağa Çeşmesi }\end{array}$ & 8 \\
\hline 2018 & $\begin{array}{c}\text { İstanbul } \\
\text { Büyükşehir } \\
\text { Belediyesi }\end{array}$ & $\begin{array}{l}\text { Süleyman Ağa Dilsiz Çeşmesi, Sineperver Valide Sultan } \\
\text { Çeşmesi, Mahpeyker Kösem Sultan Çeşmesi ve Cağalizade } \\
\text { İbrahim Bey Çeşmesi }\end{array}$ & 4 \\
\hline 2018 & Fatih Belediyesi & Vezir Çeşmesi ve Davutpaşa Çeşmesi & 2 \\
\hline \multicolumn{3}{|c|}{ Toplam } & 37 \\
\hline
\end{tabular}

Kaynak: İstanbul Büyükşehir Belediyesi Faaliyet Raporu 2012:198; 2013:251; 2014:183-184; 2015:223; 2016:221; 2017:207; 2018: 214; Fatih Belediyesi Faaliyet Raporu 2018: 312-348.

2012-2018 yılları arasında İstanbul Büyükşehir Belediyesi tarafından 35 ve Fatih Belediyesi tarafından 2 olmak üzere toplam 37 çeşme restore veya ihya edilmiştir. Ancak Beşir Ağa Çeşmesi (Sultanahmet) hem 2016 Yılı Faaliyet Raporunda hem de 2017 Yılı Faaliyet Raporunda yer almıștır. Fatih Belediyesi'nin de uhdesinde bulunan 84 tarihi çeşmeden bazılarını restore ettiği görülmektedir (Fatih Belediyesi Faaliyet Raporu 2018:312-348).

İstanbul'daki çeşme sayısıyla ilgili net bir rakam söylemek pek mümkün değildir. Bunun temel nedeni çeşmelerle ilgili geniş çaplı bir envanter çalışmasının yapılmamış olması ve çeşmelerin mülkiyetin farklı kamu kurumlarının uhdesinde bulunmasıdır. Evliya Çelebi gibi bazı muharrirler İstanbul'daki çeşme sayısını binlere kadar çıkarmıştır (Oğan, 1950:9). İsmail Habib Sevük'e (1951) göre İstanbul'un yalnız Fatih semtinde sekiz yüz çeşme bulunmaktadır. 1930 tarihli Şehremaneti Su İşleri Müdürlüğü'nün Evkaf İdaresi’ne göndermiş olduğu listede 1553 adet vakıf su tesisinden ve 795 adet çeşmenin mâmur, 7 çeşmenin de kullanılamaz durumda olduğu belirtilmiştir (Erçağ, 1987:8). İbrahim Hilmi Tanışık (1943:C.I:IV) ise İstanbul'da 219 akar, 166 tane akmaz müze ve kitaplardan derlenen 19 olmak üzere toplam 404 çeşmeden bahsetmiştir. Bu çeşmelerden kırk sekizi lahikadır. Tanışık (1943:C.I:IV) verdiği bu rakamlar dışında yok olan çeşmelerin çoğunun yalnız mevcut olan kitabelerinin Topkapı Sarayı, Türk ve İslam Eserleri ve Çinili Köşk müzelerinde korunmakta, bir kısmına da yalnızca kitaplarda adına rastlanıldığını söylemiştir. Afgan Egemen (1993:852-860) İstanbul'un Çeşme ve Sebilleri adlı eserinde Tarihi Yarımada'daki 57 semtte 265 çeşmenin adını vermiştir. Fatih Belediye Başkanı Hasan Suver ise Vezir Çeşmesi'nin ihya edilmesi sebebiyle yaptığ konuşmada Fatih'te yaklaşı 510 tane çeşme olduğunu belirtmiştir (http://www.milliyet.com.tr/vezir-cesmesi- 
yeniden-ihya-edildi-istanbul-yerelhaber-3145529/). Su Vakfi'nın envanterinde ise Tarihi Yarımada'da 346 çeşme yer almaktadır (http://www.suvakfi.org.tr/cesmeler/). Bu çalışma kapsamında yapılan araştırma ise Tarihi Yarımada'da 346 adet çeşme tespit edilmiştir. Bu rakam Su Vakfı'nın envanteri ile örtüşmektedir.

Bugün İstanbul'da son yıllara kadar bilinen 800 kadar kitabeli çeşmeden pek çoğu ortadan kalkmış ve bazılarının da yeri değiştirilmiştir (Kılınçer, 2007:7). Yukarıdaki sayısal veriler karşılaştırıldığında Fatih’teki çeşmelerin en az yarısının yok olduğu görülmektedir. Bunda yangın ve deprem gibi etkenlerin, çeşmelerin onarımsız kalması ve yol açma çalışmalarının mühim bir yer tuttuğu söylenebilir. Özellikle yol çalışmaları sırasında tarihi çeşmelerin bir engel olarak görülmesi sonucu çeşmeler yok edilmekte veya başka bir bölgeye taşımak üzere yerinden sökülüp götürülmektedir. Bu sökülme sırasında çeşmeleri kimi yerleri kırılmakta, kaybolmakta, hatta kimi zaman çalınmaktadır (Kaflı, 1951). Ayrıca asfaltlama çalışmaları da çeşmelerin yok olmasında sebep olmaktadır. Çoğu zaman asfaltlar üst üste dökülmekte ve böylece yolun zemini de gittikçe yükselmektedir. Nitekim son $40-50$ yılda devam eden bu uygulamalar yüzünden İstanbul'un pek çok semtinde zemin neredeyse metrelerce yükselmiş bulunmaktadır. Bu durum çeşmelerin bir kısmının toprak altında kalmasına yol açmıştır. Örneğin Seyyid Ali Efendi Çeşmesi zeminin yükselmesi sebebiyle büyük oranda toprak altında kalmıştır (Ek-3). Yine Gürcü Mehmed Paşa Çeşmesi'de benzer bir akıbete uğrayan çeşmelerden biridir (Ek-2).

Çeşmelerin üzerine çeşitli ilan ve sloganlar yazılması, afişsler yapıştırılması ve kenarlarına çöp atılması bu tahribatı artırmaktadır. Kadircan Kaflı’ya (1951) göre çeşmelerin başına gelen bir diğer felaket ise aşırı ilgidir. Kaflı bazı çeşmelerin mahalle sakinleri tarafından güzelleştirme adına boyandığını, sıvandığını ya da fayansla kaplandığını belirtmiştir. Çeşmelerin sık sık hırsızlık vakalarıyla karşı karşıya kaldığını söyleyen Kaflı özellikle çeşmelerin kitabe ve ayna taşı gibi üzeri işlemeli parçalarının çalındığını belirtmiştir. Ayrıca Vakıflar Genel Müdürlüğü kimi sebilleri büfe olarak kiraya vermektedir. İşletmeciler kimi zaman bu sebilleri tahrip edebilmektedir. Çeşmelerin bu kadar hızlı yok olmasında bölünmüş yönetim, tarihi eserleri zarar verenlere karşı uygulanan yasal hükümlerin yetersiz kalması, insanlarda bu konuda yeterince bilincin oluşmamış olması, bilinçsiz onarımlar sonucu anıtların belge niteliğini kaybetmesi ve tahribe uğraması etkili olmaktadır (Yılmaz: 79). Hayat mecmuası çeşmelerin yok olmasında eğitim ve ihmal boyutuna dikkat çekerek Milli Eğitim'de kendi tarihini öğrenmeyen ve sanat tarihi derslerinde ise kendi sanatı yerine Yunan ve Roma medeniyetlerini öğrenen gençlerin muhteşem türbe ve sebillerin duvarlarını iğrenç yazılarla pisletmelerinin normal olduğunu belirtmiştir. Sünnetçilerin cami, çeşme, sebil duvarlarına ilan yapıştırdıklarını belirten mecmua siyasi partilerin de bu ata yadigârı eserlerin duvarlarına yazıp, mermerleri berbat etiklerini ve Kethüda Yahya Ağa Çeşmesi'nin Perşembepazarı'nda demirci dükkânları sakinleri tarafından nasıl yok edildiğini ayrıntılarıyla aktarmıştır. Mazisinden kopartılan nesillerin öz varlıklarını kendi elleriyle imha ettiklerini yazan Hayat Milli Eğitim'de millî ruh verilmeyen çocukların çoktan büyüdüklerini ve Maçka'da yanı başında yüzlerce gencin mimarlık tahsil ettiği fakülte bulunmasına rağmen Bezmiâlem Valide Sultan Çeşmesi’nin çöplük olarak kullanıldığını yazmıştır (Gömdüğümüz Çeşmeler, 1976).

28 Mart 2013 tarihinde yürürlüğe giren İstanbul Büyükşehir Belediyesi Belediye Kuralları Yönetmeliği’yle belirlenen çeşmeler dışında çeşmelerden su almak, çeşmenin etrafını kirletmek, zarar vermek ve devamlı işgal etmek, bu yerlerde eşya, taşıt aracı veya hayvan yıkamak, muslukların yerini değiştirmek yasaklanmıştır (İBB Belediye Kuralları Yönetmeliği, 2013:683). Böylelikle belediye tarihi çeşmelere yönelik önlem almaya çalışmıştır. Ancak çeşmelerden iş yerleri tarafından su alınmasına, araba ve halı yıkanmasına tam anlamıyla engel olunamamıştır. Bu sebeplerden dolayı bazı mahalle sakinleri bölgelerindeki çeşmelerin köreltilmesini talep etmektedir.

\section{SONUÇ VE ÖNERILLER:}

Araştırma sonucunda toplam 346 tane tarihi çeşme tespit edilmiştir. Bu çeşmelerden 306'sının suyunun akmadığ1 ve asli görevi yerine getirmediği görülmüştür. Yine bu 346 çeşmeden 56'sının acil müdahale edilmezse yıkılma tehlikesi ile karşı karşıya olduğu, çeşmelerden 26'sının sprey boyalarla boyandığı, bir kısmının yol seviyesinin yükselmesi sonucunda yol altında kaldığı, büyük çoğunluğunun musluğunun kırık ve kitabelerinin kaybolduğu tespit edilmiştir. Ayrıca kısmen onarılan ve restore edilen çeşmeler olmakla beraber çeşmelerin büyük bir kısmının bakımsız olduğu, bazılarının çöplük olarak kullanıldığı, bazılarının ise inşaat işleri sebebiyle zarar gördüğü görülmüştür. Yine tarihi çeşmelerin bazılarının evsiz insanlar tarafından barınak olarak kullanıldığını görülmüştür.

İnsanın değerini bilmediği şeyi korumadığını göz önüne aldığında insanları bu konuda bilinçlendirmenin çok önemli olduğu bu çalışmayla bir kez daha ortaya çıkmıştır. Çalışma sonucunda Türkiye'de tarihi değerleri koruma konusunda 
önemli eksiklikler olduğu da görülmüştür. Tarihi Yarımada, İstanbul'a dışarıdan gelen insanların genelde ilk uğrak noktası olması sebebiyle yoğun bir nüfus baskısı altındadır. Ayrıca buraya göç eden insanların çoğunlukla ilk amaçları ekonomik durumlarını düzeltmek olduğundan kültürel ve tarihi eserleri korumak kendileri için ilk sırada yer almayabilmektedir. Bu sebeple Tarihi Yarımada'da yaşayan insanların ilk olarak ekonomik durumlarının geliştirilmesi, ikinci olarak da kültürel mirası koruma konusunda bilinçlendirilmeleri gerekmektedir. Bunun için öncelikte Fatih'te okul çağındaki çocuklardan başlayarak mümkün olduğunca herkese bu konuda yerinde eğitimler verilmelidir.

$\mathrm{Bu}$ araştırmanının amaçlarından biri çalışmada yer alan öğrencilerin bilinçlendirmesiydi. Öğrencilerin saha araştırmalarından sonra yaptıkları değerlendirmeler bu amacın büyük oranda gerçekleştĭgini göstermektedir (Ek-4). Kimi zaman önyargıyla yaklaştıkları bu çalışmanın sonunda fikirlerinin büyük oranda değiştiği görülmektedir. Bu çalışmayla yaşadıkları şehri aslında ne kadar az tanıdıklarını farkına varan öğrenciler tarihi hüviyeti olan çeşmelerin durumlarını yakında müşahede ettiler. Sadece çeşmelerin değil tarihi eserlere de yeterince önem verilmediği değerlendirmesinde bulunan öğrenciler bu çalışma sayesinde şehrin farklı bölgelerinde gezme ve farklı insanlarla tanışma imkânına kavuşmuşlardır. Çalışmaya katılan Fatih Gelenbevi Anadolu Lisesi öğrencileri sadece tarihi eserleri koruma konusunda bilinçlenmediler aynı zamanda akranları arasında bu konuda örnek bir rol üstlendiler. Araştırmanın bir diğer amacı olan ilgili kurumlara tarihi çeşmelerin korunmasıyla ilgili destek olunması, uyarıda bulunulması içinde çalışma sonucunda hazırlanan katalog İstanbul Büyükşehir Belediyesi ve Fatih Belediye'nin ilgili birimleriyle paylaşılmıştır ve diğer ilgililerin hizmetine sunulmuştur.

Tarihi dokunun korunabilmesi için canlı hüviyetinin korunması gerekmektedir. Bu yüzden çeşmelerden su akması elzemdir. Mesela İtalya'daki şehirlerin en önemli turistik çekim noktalarından biri tarihi çeşmelerdir. Konum ve mimari özellikleri bakımından birçok bölüme ayrılan zengin bir çeşme kültürüne sahip olan İtalya'da çeşmeler "piazza" adı verilen meydanların en önemli peyzaj öğeleridir. Neredeyse her meydanda bir çeşme bulunmakta ve bu çeşmelerden su akmaktadır. İlk yapıldıkları gibi yaşamaya devam etmekte olan bu çeşmeler canlı hüviyetleriyle meydanların kamusallığını arttırmaktadırlar. Fakat Türkiye'deki çeşmelerin aynı şansa sahip olmadıkları görülmektedir. Bunun en önemli nedeni çeşmelerin fonksiyonsuz bırakılması, bakımsızlık, kötü kullanım ve onarımlar, kasıtlı tahripler ve bilinçsizliktir (Kaya, 2011:44-48). Ayrıca bazı mahallelerde çeşmelere musluk takılması bazı mahalle sakinleri tarafından istenmemektedir. Bunda da çeşmelerin etrafının zamanla kirlenmesi, burada halı veya araba yıkanması etkili olmaktadır. Çeşmelerden su akmamasının bir diğer sebebi de çeşmelere takılan muslukların çalınmasıdır. Suyu akmayan çeşmelerin zaman içerisinde varsa yalak kısımları kırılmakta, yazı tahtasına dönüşmekte ve çöplük olarak kullanılmaktadır. Her biri Türk kültürünün önemli bir nişanesi olarak İstanbul'un farklı sokaklarını süsleyen çeşmeler yapılan çalışmalara rağmen maalesef büyük bir tahribata uğramaya devam etmektedir.

Tarihi Yarımada'daki çeşmelerin bir kısmı Vakıflar Genel Müdürlüğü’nün bir kısmı Fatih Belediyesi’nin ve bir kısmı da İstanbul Büyükşehir Belediyesi’nin mülkiyetinde yer almaktadır. Bu üçlü bölünmüşlük çeşmelere yönelik ortak bir çalışma yapılmasının önündeki engellerin başında gelmektedir. Farklı kurumlar arasındaki koordinasyon zorluğu çeşmelere müdahaleyi zorlaştırmaktadır. Çeşmeler başta olmak üzere Tarihi Yarımada'daki kültürel mirası kurtarabilmek için hala yapılabilecek bazı şeyler bulunmaktadır. İlk olarak ivedilikle Tarihi Yarımada'da tüm paydaşların katıldığı bir üst kurul veya Suriçi Tarihi Alan Başkanlığı kurulmalıdır. Suriçi Tarihi Alan Başkanlığı'nın kurulması bu bölgenin korunmasını kolaylaştıracaktır. Ancak bu kurumun zaman içinde hantallaşmasını önleyecek önlemlerin de peşinen alınması gerekmektedir. Ayrıca Belediyelerin tarihi eserleri koruması için ödemeleri gereken katkı paylarını ödemeleri tarihi eserlerin korunması için ihtiyaç duyulan fonun oluşmasına yardımcı olacaktır. Okullarda öğrencilerin bu konuda bilinçlendirilmesi gelecek nesillerin bu tarihi mirasa sahip çıkmasını kolaylaştıracaktır. Çeşmelerin turizme kazandırılması için de çalışmalar yapılmalıdır. Özellikle farklı dönemlere ait çeşmeler üzerinden yürüyüş parkurları oluşturulabilir. İstanbul'da yaşanan çarpık kentleşme ve plansız büyümenin bir an önce kontrol altına alınması gerekmekte ve yetkililerin bu konuda acil önlem alması gerekmektedir. İstanbul'da başta çeşmeler olmak üzere tarihi dokunun korunması herkesin görevidir.

\section{Etik Standart ile Uyumluluk}

Çıkar Çatışması: Yazarlar herhangi bir çıkar çatışmasının olmadığını beyan eder.

Etik Kurul İzni: Bu çalışma için etik kurul iznine gerek olmadığını beyan ederim.

Finansal Destek: Yok

Teşekkür: Yok. 


\section{KAYNAKÇA:}

Arel, A. (1975). Onsekizinci Yüzyıl İstanbul Mimarisinde Batılılaşma Süreci, İstanbul: İ.T.Ü. Mimarlık Fakültesi Baskı Atölyesi.

Asatekin, N.G. (2004). Kültür ve Doğa Varlıklarımız Neyi, Niçin, Nasıl Korumalıyız?, Ankara: Kültür Varlıkları ve Müzeler Genel Müdürlüğü Yayınları.

Aslanapa, O. (2004). Osmanlı Devri Mimarisi, İstanbul: İnkılap Kitapevi.

Aysel, N. R. (2008). İstanbul'un Tarihi Su Sistemleri: Kırkçeşme Tesisleri, Tarihi Su Yapıları Konferansı Bildiri Kitab1, İzmir, 26-27 Haziran 2008, s.223-224.

Ayverdi, E. H. (1953). Fatih Devri Mimarisi, İstanbul: İstanbul Fetih Derneği Neşriyatı.

Ayverdi, E. H. (1958). 19. Asırda İstanbul Haritası, İstanbul: İstanbul Fetih Derneği Yayınları.

Banarlı, N. S, (1958). Çeşmeler, Türkiye Turing ve Otomobil Kurumu Bülteni, Mart 1958, s. 3-4.

Çetintaş, S.(1944). Türklerde Su, Çeşme ve Sebil, İstanbul: Güzel Sanatlar.

Çubukçuoğlu, Z. (1936, 11 Eylül). Çeşmeler, Bentler, Kuyular, Son Posta. Erişim Adresi: http://earsiv.sehir.edu.tr:8080/xmlui/bitstream/handle/11498/2939/001501878006.pdf?sequence=3

Demirel, Ö. (1992). Sivas Çeşmeleri, AÜ OTAM Dergisi, S.3, s.169-178.

Egemen, A. (1993). İstanbul'un Çeşme ve Sebilleri, İstanbul: Arıtan Yayınevi.

Erçağ, B. (1987). İstanbul Su Mimarisinde Yapı ve İşlevleriyle Çeşmeler, İlgi, 1987, No.49, s. 2-8.

Ertuğ N. (Ed.). İstanbul Tarihi Çeşmeler Külliyatı, İstanbul: İSKİ Yayınları.

Eyice, S. (1993), Çeşme, DİA, C.VIII, s. 277-287.

Fatih Belediyesi Faaliyet Raporu 2018.

Gömdüğümüz Çeşmeler (1976, 10 Haziran). Hayat Mecmuası, s.8-10.

Gündüz, M. (2017). Zaman Akıyor Çeşmelerimiz Yok Oluyor, FGAL, İstanbul.

İgüs, E. (2014). XVIII. Yüzyıl İstanbulu'nda Fiziki Çevre, Meydan Çeşmeleri ve Çeşme Meydanlarının Etrafında Oluşan İstanbul Meydanları. Uluslararası Osmanlı İstanbulu Sempozyumu-II; 27-29 Mayıs 2014, s.675-692.

İstanbul Büyükşehir Belediyesi Faaliyet Raporu 2012

İstanbul Büyükşehir Belediyesi Faaliyet Raporu 2013.

İstanbul Büyükşehir Belediyesi Faaliyet Raporu 2014.

İstanbul Büyükşehir Belediyesi Faaliyet Raporu 2015.

İstanbul Büyükşehir Belediyesi Faaliyet Raporu 2016.

İstanbul Büyükşehir Belediyesi Faaliyet Raporu 2017.

İstanbul Büyükşehir Belediyesi Faaliyet Raporu 2018.

İstanbul Büyükşehir Belediyesi Belediye Kuralları Yönetmeliği, Kabul Tarihi ve Numarası: 15.03.2013, 683.

İstanbul'un Kitabı (1957), İstanbul: İstanbul Vilayet Neşriyat, 
Kaflı, K. (1951, 20 Mart). Çeşmelere Su, Yeni Sabah.

Kaya, N.Ö. (2011). İtalya'daki Köprü ve Çeşme Yapılarının Türkiye'deki Benzerlerinin Korunması Açısından İrdelenmesi. II. Su Yapıları Sempozyumu - 16-18 Eylül 2011, Diyarbakır, s.43-49.

Kılınçer, G. (2007). Kaybolan Çeşmeler, İstanbul: Kuveyt Türk Yayınları.

Kırkçeşme Suları İhya..., (1950, 17 Temmuz). Milliyet, s.7.

Köprülü Hemşire Çeşmesi, (1985, 9 Ekim). Cumhuriyet, s.11.

Mango, C. (2006). Bizans Mimarisi, Ankara.

Oğan, A. (1950). Yeniden Kurulan Bereketzade Çeşmesi, Türkiye Turing ve Otomobil Kurumu Bülteni, Aralık 1950, s.9-10.

Schütte, W.(1942, 7 Ağustos). Yabancıların Mimar Gözüyle Türk Çeşmeleri, Cumhuriyet, s.2.

Sefer, N.- Ahunbay Z. (2015). Eminönü’nün Haliç Kıyı Bölgesindeki Vakıf Kültür Mirası'nın 1920- 2015 Arasında Geçirdiği Onarımlar ve Uğradığı Kayıplar, Restorasyon Yıllığı Dergisi, 10: 78-120.

Sevük, İ. H. (1951). Şadırvanların Şehriyanları, Erişim Adresi:

http://earsiv.sehir.edu.tr:8080/xmlui/bitstream/handle/11498/27815/001640157010.pdf?sequence=1

Strzygowski ve Forchheimer (1893). Die Byzantinischen Wasserbehalter von Konstantinopel, Wien.

Ünsal, B. İstanbul'un İmarı ve Eski Eser Kaybı”, Türk Sanatı Tarihi Araştırma ve İncelemeleri II, İstanbul: İstanbul Devlet Güzel Sanatlar Akademisi Türk Sanatı Tarihî Enstitüsü Yayınları: 2.

Tanışık, İ. T. (1943). İstanbul Çeşmeleri, İstanbul: Maarif Matbaası, C.I.

Tarcan, S.S. (1938, 26 Eylül). “Akmıyan Çeşmeler”, Cumhuriyet.

Tarihi Çeşmeler (1939, 22 Haziran). Cumhuriyet, s.2.

Tarihi İstanbul Çeşmeleri (1985, 18-19 Mart). Cumhuriyet, s.5.

Tarihi İstanbul Çeşmeleri, (1986, 4 Nisan). Cumhuriyet, s.14.

Tarihi İstanbul Çeşmeleri Kurtarılmalıdır (1985, Mart.) Güneş.

Yılmaz, İ. A. Koruma ve Yaşatma Açısından Yaklaşımlar, s.78-79 Erişim Adresi:

(http://earsiv.sehir.edu.tr:8080/xmlui/bitstream/handle/11498/3094/001502226006.pdf?sequence=3).

https:/gis.fatih.bel.tr/webgis/

http:/www.milliyet.com.tr/vezir-cesmesi-yeniden-ihya-edildi-istanbul-yerelhaber-3145529/

http://www.suvakfi.org.tr/cesmeler/eminonu/12/

http://www.suvakfi.org.tr/cesmeler/fatih/15/

http://www.suvakfi.org.tr/cesmeler/ 


\section{EKLER:}

Ek-1: Davutpaşa Çeşmesi

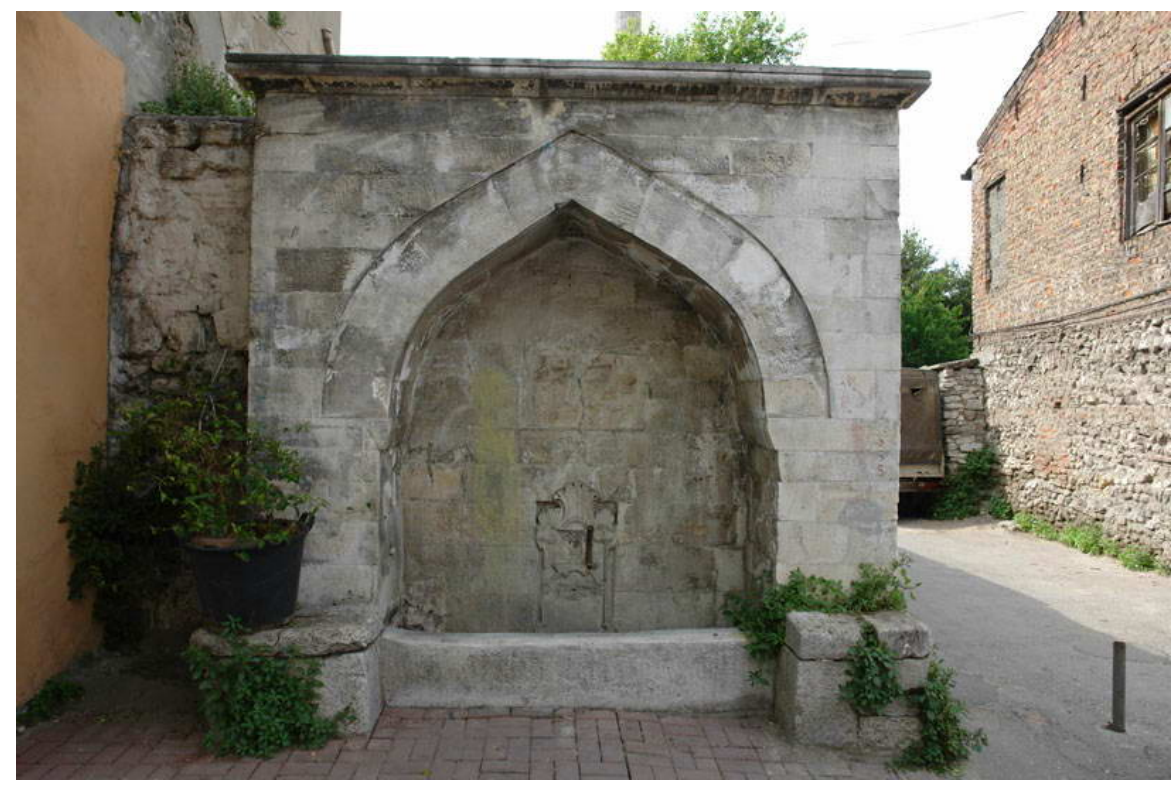

Ek-2: Gürcü Mehmed Paşa Çeşmesi

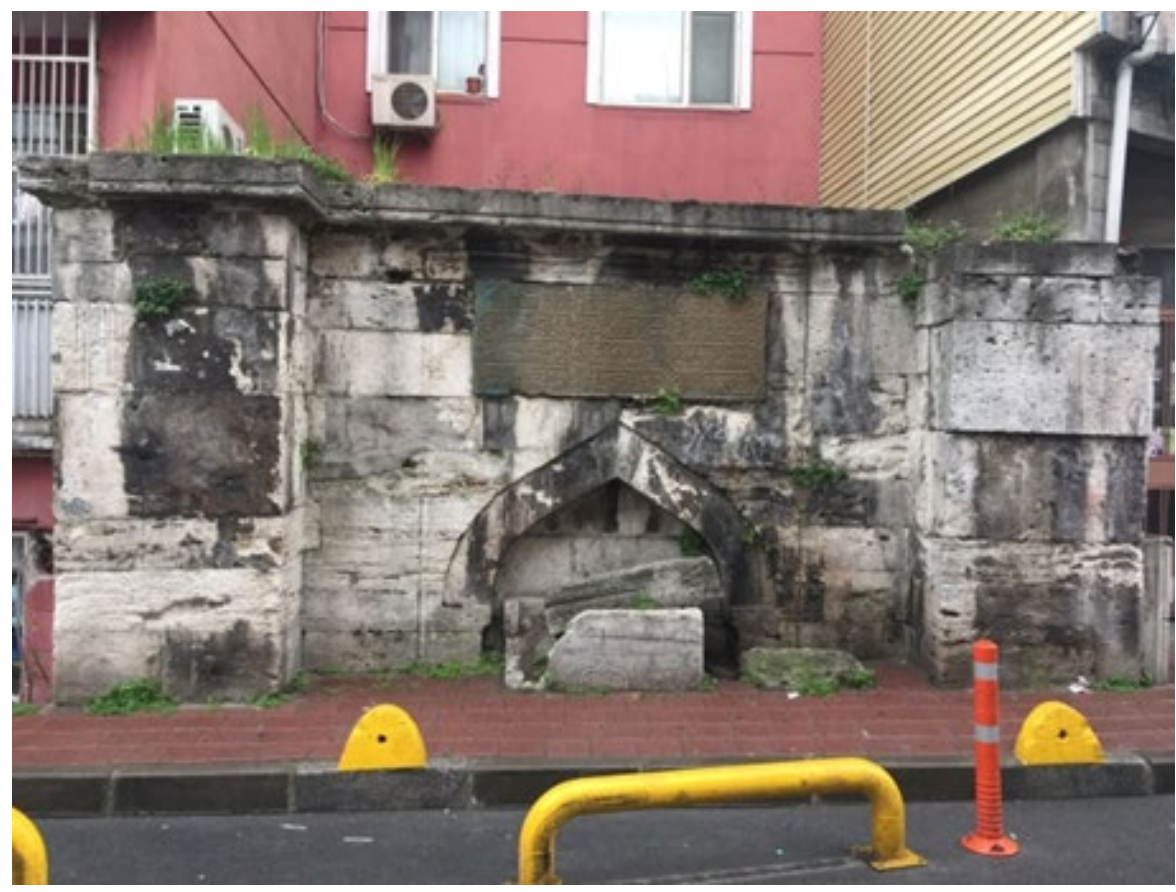




\section{Ek-3: Seyyid Ali Efendi Çeşmesi}

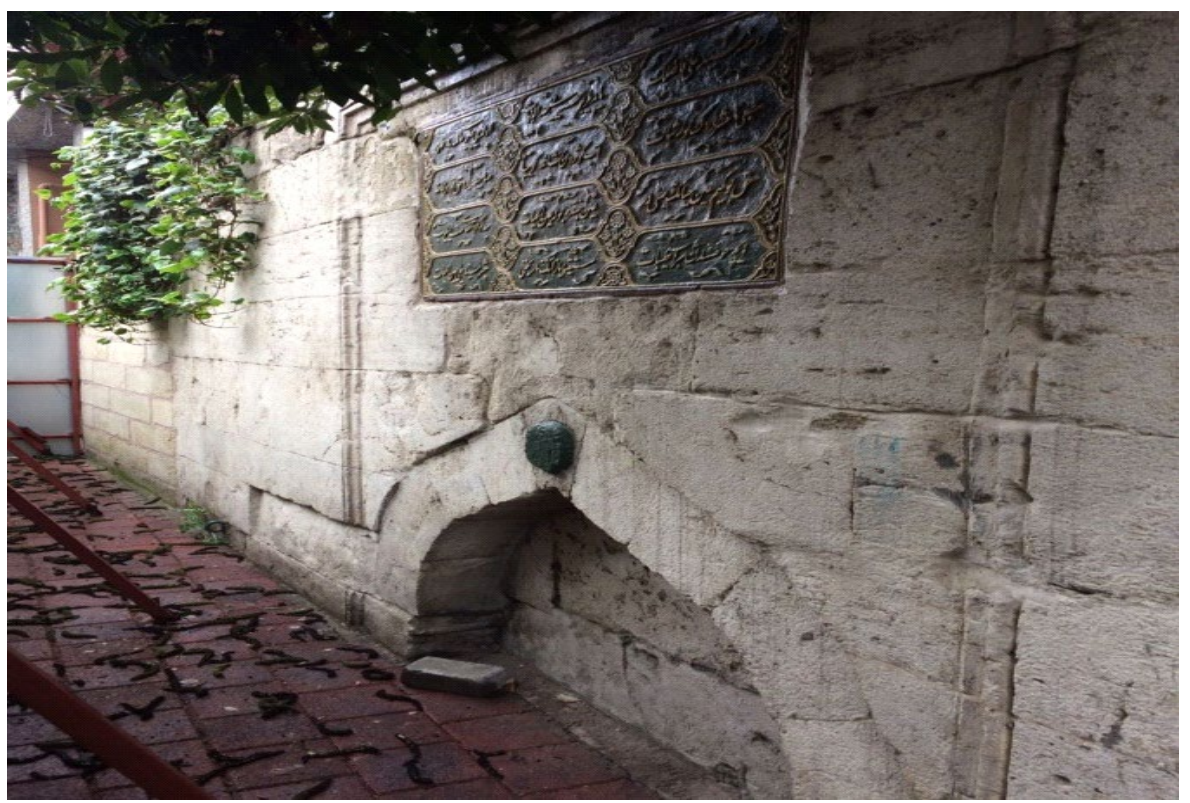

\section{Ek-4: Saha Çalışması Yapan Öğrencilerin Projeyle İlgili Değerlendirmeleri}

"Yapılan geziler sonucunda anlaşılmıştır ki, başta yerli halk olmak üzere belediye yönetimi, ilgili eserler hakkında tutarsız ve vurdumduymaz kalmışlar ve günlük hayatın getirmiş olduğu yaşam standartların etkisiyle kültürümüze sahip çıkmamışlardır. Günümüz dünyasında anlamını yitiren dedelerimizin eserleri gençlerin eğlence kaynağ olmuştur ve üzerine yazı yazmak ve çeşitli bölümlerini kırmak sureti ile zarar verilmiş̧ir. Öz kültüründen oldukça uzakta, küresel kültürün tesiri altında dünyaya gelmiş biz gençler için oldukça etkileyici olan bu görev, bizlere dedelerimizin dünya, sanat ve epik anlayıșının yanı sıra günümüz halkının duyarsızlığını, ilgisizliğini, saldırgan ve barbar tutumunu da tatmamıza vesile olmuştur. Çeşmeler için genel olarak şu söylenebilir; özünü kaybetmişler.”

"Ne kadar güzel bir ilçede yaşadıklarının aslında farkında değiller. Çünkü çevrelerinde o kadar güzel eserler varken onlar sahip çıkmak ve korumak yerine onları daha kötü duruma getiriyorlar. Bu hepimizin suçu aslında ama farkında olan insan sayısı çok az. Bunun dışında birde bu eserlerin yanına, önüne ve arkasına o kadar kötü binalar yapılmış ki gerçekten eser orada kendini kaybetmiş vaziyette... İnsanlar bunları umursamıyor, sözde tarihine âşık bu millet bile bile bu tarihten kalan sayılı esere zarar vermeye ve onları yok etmeye devam ediyor. Bu durumu biz gezerken kanıtladık. Çünkü Alman Mavileri adlı kitapta tarihteki mahallemiz ile günümüz mahallemizi karşılaştırdığımızda Dibek Camii ile Hüsrev Paşa Türbesi arasında bir çeşme bulunurken şimdi o çeşmenin yerinde onlarca biçimsiz bina var. İşte bu da aslında bizim eserlerimize gereken önemi ve özeni göstermediğimizin gerçek bir kanıtı.”

"İlk çeşmeyi bulduğumuzda çok mutlu olduk. Zaten ondan sonrası çorap söküğü gibi geldi. Her girdiğimiz bir sokakta çeşme bulduk. Fakat çeşmelerin önemsenmemesi, yıpranması, duvarlarındaki yazılar ve etrafindaki çöpler bizi hayal kırıklığına uğratıyordu. Bu şekilde tüm çeşmeleri bulduk ve fotoğraflarını çektik... Çeşmelerin fotoğraflarını çekerken bizi turist sandılar. Turist olmadığımızı anlayınca da garip bakışlara maruz kaldık.”

"Bu çalışmanın benim için faydası; yaşadığım şehri ne kadar az tanıdığımı fark ettim ve aslında öyle izlemek için baktığımız eski eserleri izlensin diye yapmadıklarını fark ettim ve şuana kadar 'gezdim' dediğim yerleri aslında gerçekten gezmediğimi öğrendim... Evet, çalışma oldukça zordu ve bizi oldukça yordu. Bunu inkâr edemem ama beni 
daha fazla para için ya da daha lüks yaşayacağını sandığı için yaşadığı yeri beton yığını haline getiren insanlardan biri olmaktan kurtard1."

"Belki de tarihi eserlerin boyut olarak en küçüklerinden biri olan çeşmeleri aramak -en önemlisi de aradığımız çeşmeler hakkında bilgi sahibi olmak- duyarlılığımızı arttırdı. Sonuç olarak "Tarihi Çeşme" arayışımız bize geçip gittiğimiz yerleri daha yavaş ve en önemlisi görerek geçmemizi bilhassa geçmemi sağladı, sağlamakta. İste bu mini turun bizi ilgilendiren kısmının bu olduğunu düşünüyor, bu düşüncelerimi de hayatımda uygulamaya çalışıyorum."

"Bir Türk olarak acaba çevremizde gördüğümüz şeylere ne kadar dikkatli bakıyoruz? Aslında bir turist gözüyle bakabilsek, çevremizdekileri o denli ince ayrıntıyla inceleyebilsek sanırım bir şeylerin değerini daha iyi anlarız. İşte biz bu çalışma çevremizi (sadece bir mahalle olsa bile) inceleme fırsatı bulduk. Hiç tanımadığımız, bilmediğimiz bir mahallede Fransız kalmak gibi bir şey oldu yaşadıklarımız."

"Bu çalışma bizim tarih eserlerimize ne kadar sahip çıkamadığımızı gösterdi bana. İstanbul'u sadece birkaç sembolik tarihi yerle tanımak ona büyük haksızlık. Bu çeşmeler eski dönemlerde sosyal hayatın büyük bir parçasıydı. Su ihtiyaçları buradan giderilir belki nice komşu sohbetleri burada edilirdi. Elbet günümüzde o zamanki kadar önem arz etmiyorlar ama yine de bu çeşmeleri korumak, hem kültürel hem manevi havayı yeniden yaşatmak adına atılacak iyi bir adım olabilir. Turistik açıdan da oldukça değerliler."

"Bu çalışma bana sadece tarih anlamında değil kişisel anlamda da birçok şey kattı. Gezip gördüğümüz çeşmeler ve tarihi eserler hakkında araştırma yaparken tarihimiz hakkında bilgiler öğrenmiş oldum. Çeşmeleri bulmak sandığım kadar kolay olmadı. Çeşmeleri bulmak için kütüphanede derin bir araştırma yaptık ve haritaları inceledik. Bu sayede harita incelemeyi ve ansiklopedilerde araştırma yapmayı daha pratik bir şekilde öğrendim."

“Öncelikle bu çalışma bize verildiğinde ön yargılı yaklaşarak burun kıvırmıştık ancak hem kütüphanede hem de gezi sırasında oldukça eğlendik ve İstanbul'da yaşamamıza rağmen bilmediğimiz onlarca yer öğrendik ve hafizamıza bu yerler kalıcı bir anı olarak kazındı. Bu çalışmanın bize kattıkları ise bahsettiğim gibi bilmediğimiz hatta beklide hiç rastlamayacağımız onlarca sokak yüzlerce insanla tanıştı."

"Çalışma sonucunda tarihi eserlere gerçekten hor davranıldığını görmek bizi üzdü. En sağlam görünen eserin bile kapısında çizikler, kenarında kırıklar, önünde çöpler vs. vardı. Bu ödev bazı şeyleri sorgulamamıza ve farkına varmamıza yardım etti. Aynı zamanda önceki paragraflarda belirttiğim gibi esnafın yardımını almamız bu halkın çok güzel olduğunu bize tekrar hatırlattı.

"Bu çalışma bizim için oldukça öğretici ve düşündürücü olduğunu rahatlıkla söyleyebiliriz. Çalışmamızın yapım aşamasında hepimiz mahvettiğimiz tarihimizle yüzleşirken meraklıydık ve bu merakımız umarız ki sadece bu çalışmayla sınırlı kalmaz.” (Gündüz, 2017:XVII-XXVIII). 